\title{
Socio-Economic Implications of the Coronavirus Pandemic: Early Review and Projections, Nigeria in Focus
}

\author{
Stanley C N $\mathbf{N}^{1}$, Nkporbu A $\mathbf{K}^{2}$, Stanley P C ${ }^{2}$ \\ ${ }^{1}$ Department of Pharmaceutical Microbiology, Faculty of Pharmaceutical Sciences, University of \\ Port Harcourt, Nigeria. \\ ${ }^{2}$ Department of Neuropsychiatry, University of Port Harcourt Teaching Hospital, Port Harcourt, \\ Nigeria
}

*Corresponding Author: Stanley P.C, Department of Neuropsychiatry, University of Port Harcourt Teaching Hospital, Port Harcourt, Nigeria

\begin{abstract}
Background: The coronavirus pandemic (COVID-19) is both a serious threat to human existence and at the same time causing a lot of traumatic socio-economic losses to people and nations globally.

Aim: The aim of this study was to assess the socio-economic implications of the coronavirus pandemic on the general population, with focus in Nigeria.

Methodology: The study was done through review of the available health service records in the hospital from December 2019 to mid April, 2020, internet information, electronic and print media. Approval was obtained from the Hospital Ethical Committee to access the records. This was also followed by active search of available online data from the Nigerian Centre for Disease Control (NCDC) and other countries Centre for Disease Control, the World Health Organization as well as emerging literatures from National Media. As it was not possible to do a true systematic review, this was only a narrative review. Data were presented in tables.

Results: The review found a high level of fear and apprehension associated with the COVID-19 Pandemic among the general public occasioned by huge National, State as well as individual socio-economic loss and difficulties due to the lockdown and restrictions including markets, shops and other private and public businesses. As a result, many especially those on small and middle cadre employments have lost their jobs, there increased dependency, hunger, sufferings and has posed a lot of restiveness and social insecurity.

Conclusion: Extensive outbreak of this infection to a pandemic scale such as COVID-19, with the associated huge losses, disruption of businesses and global economic loss has caused unprecedented global socio-economic loss. It is therefore important affected countries should as a matter of urgency institute and implement adequate palliative measures that will help ameliorate and cushing the socio-economic hardship experienced by its citizenry to improve the social, economic and emotional well-being and avert a possible looming socio-economic and Mental Health crisis.
\end{abstract}

Keywords: Socio-Economic Implications, Coronavirus Pandemic, Early Study, Projections, Port Harcourt Nigeria.

\section{INTRODUCTION}

The coronavirus (COVID-19) pandemic has no doubt had negative toll on the human race, with huge socio-economic impact on manufacturing, supply chains, services, business such as tourism and travel as well as significant drop in global socio-economic security. ${ }^{1-3}$ In late December, 2019, a new variant of virus called coronaviru sout break started from Wuhan, Hubei Province of China as an epidemic.Covid19 presents with non-specific clinical manifestations caused by SARS-CoV-2(severe acute respiratory syndrome Coronavirus-2). ${ }^{4-10}$
Coronaviruses are a group of enveloped viruses with non-segmented, single stranded and positive-sense RNA genomes. SARS-CoV-2 belongs to the beta subgroup of coronaviruses and has $70 \%$ in the genome to SARS-CoV. ${ }^{6}$ Covid-19 virus spreads mainly through respiratory droplets of infected persons during speaking, sneezing or coughing. This transmission can occur directly by contact with an infected person, indirectly by contact with surfaces contaminated by droplet from COVID19 positive patients or other less authentic routes such as faeces. ${ }^{4-11}$ 
The COVID- 19 has since spread beyond China constituting a huge global emergency and concern. ${ }^{12}$ On $30^{\text {th }}$ January, 2020, the World Health Organization(WHO) declared the outbreak a Public Health Emergency of International Concern(PHEIC). ${ }^{13}$ By March 11, 2020, the infection has spread across several countries of the world causing the WHO to again declare it a pandemic. ${ }^{14}$ The COVID-19 outbreak has since spread to over 200 countries and territories in every continent and one international conveyance across the globe. ${ }^{12}$ While there are ongoing efforts to curtail the spread of infection which is almost entirely driven by human-to-human transmission, ${ }^{11,19}$ as at $21^{\text {st }}$ April, 2020, over 2.5 million persons have been infected globally with about 177,000 deaths recorded. ${ }^{13-16}$ Nigeria recorded its index COVID-19 case on the $27^{\text {th }}$ of February, 2020, and by $21^{\text {st }}$ April, 2020, the number of confirmed cases has risen to 782 with 25 deaths. ${ }^{18}$

Beyond the tragic health hazards and human consequences of the COVID-19 pandemic, the economic uncertainties, and disruptions that have resulted come at a significant cost to the global economy. ${ }^{20-32}$ The United Nations Trade and Development Agency (UNCTAD) put the cost of the outbreak at about US\$2 trillion in 2020. The slowdown in the global economy and lockdown in some countries, such as Italy, Spain and most Euro zone economies and beyond, as a result, COVID-19 has also taken its toll on the global demand for oil. ${ }^{21-23}$ The decline in oil demand is estimated to surpass the loss of nearly 1 million barrels per day during the 2007-08 recession. ${ }^{20-22}$ Oil production and other oil related activities equally slowed down. The oil prices have fallen remarkably, and many countries have had to adjust their budget. ${ }^{20-22}$ This is also coming at a time when two key players in the global oil industry - Russia and the OPEC cartel - are at loggerheads on the decision to cut output. ${ }^{20}$

For most developing economies, the odds of deepening into an economic downturn are gradually expected as the global coronavirus outbreak puts severe pressure on the economy. ${ }^{23-30}$ For Nigeria, the country is still sluggishly grappling with recovery from the 2016 economic recession which was a fall out of global oil price crash and insufficient foreign exchange earnings to meet imports. ${ }^{20-22}$ In the spirit of economic recovery and growth sustainability, the Nigerian federal budget for the 2020 fiscal year was prepared with significant revenue expectations but with contestable realizations. The approved budget had projected revenue collections at N8.24 Trillion, an increase of about 20\% from 2019 figure. The revenue assumptions are premised on increased global oil demand and stable market with oil price benchmark and oil output respectively at $\$ 57$ per barrel and 2.18 Million Barrels Per Day.

The global population has continued to experience unbearable consequences. ${ }^{23-33}$ There have been lockdowns in many parts of the world in order to contain the spread of the deadly viral disease outbreak. Flights especially international corporations have shut down for operations because of closure of international boarders by most countries. Sector-specific implications and impacts could vary. For example, the impacts on the global aviation and tourism sectors are a result of the implications of the pandemic on global travel. As discretionary spending by consumers continues to decline, cruise companies, hotels, and hospitality are facing declining demand and patronage. For example, in Hungary alone, about 40 to $50 \%$ of hotel reservations have been canceled. Also, the pandemic is placing up to 8 million jobs in the leisure and hospitality sector at risk, with travel crashes and cancellations expected to continue, it has been stated that more than half of the jobs in the United States which is about 80 million may be in jeopardy

The decision to close educational institutions and schools around the globe in an attempt to contain the pandemic has also led to a soaring number of children, youth and adults not attending schools. According to UNESCO Monitoring report on COVID-19 educational disruption and response, the impact of school closures in the over 100 countries that have implemented the decisions around the world has impacted over half of the global students' population. ${ }^{25}$ These educational disruptions are being escalated particularly for the most vulnerable members of society.

The global reactions to the COVID-19 infection has been worrisome. There has been panic buying of both food and hygiene products. In fact, the scramble for supplies with individuals and family stocking up every item even with no evidence of impending shortage. Worse still is that some resellers hawk hygiene product at hyper-inflated prices, and there has been report of some countries hijacking a whole consignment of surgical masks meant for 
different destination. In another reaction, America, Europe and the UK initially saw incidents of xenophobic outburst against Asians

Furthermore, movements have been greatly restricted in many countries except for workers on essential duties such as hospital, security, utility services. ${ }^{24-30}$ The others have been asked to stay at home. About 1 month ago, the World Bank said that the economy of the world has leaped into recession. This appears to be worse with the daily earners which constitute the majority of the population of many countries especially developing economies. ${ }^{33-36}$ In fact, the slowdown in economic activities has made an unprecedented number of people lost their job globally. Apart from the effects of demand and supply, COVID-19 has greatly influenced financial markets with the sharp fall in prices of bond yields, oil and equity. In the US, 10-year treasury yields have tumbled below $0.5 \%$ and equity prices on major stock indices globally have fallen. There is also still potential for further market disruption. There are both individual as well as institutional experiences of liquidity stress, including limited access to credit facilities with increase tendency for default private debt, both corporate and household..

The International Monetary Funds (IMF) has recently remarked that the global economy will contract by $1.6 \%$. A number of proactive measures are already being put in place. ${ }^{34-37}$ Central Banks around the world have already proactively intervened to calm markets and show commitment using all possible measures ranging from adding liquidity to increasing asset purchases. ${ }^{37-40}$ For example, the Peoples bank of China has already pumped more than USS240 billions of liquidity into the financial system as a countermeasure to the virus.

Generally, hunger and sufferings have increased among various population with eminent fear of possible faming because the farming activities have drastically reduced, further worsened by insurgency and activities of herdsmen. The tendency for crimes has equally increased as some people are prone to engaging in any acts that can guarantee them the next meal. The global and national outcry has made many countries and state to release many metric tones of their grain reserve.

The emergence of COVID-19 and its increasing incidence in Nigeria has called for drastic review and changes in the earlier revenue expectations and fiscal projections. Furthermore, the current state of the global economy poses more difficulties ahead as the oil price is currently below US $\$ 30$ with projections that it will decrease further going by the price war among key players in the industry. Unfortunately, the nation has grossly underachieved in setting aside sufficient buffers for difficult day as it faces in the coming days. The last unemployment report released by the National Bureau of Statistics (NBS) ranks Nigeria 21st among 181 countries with an unemployment rate of about $23.1 \%$. The country has also been rated as the poverty capital of the world with an estimated 87 million people living on less than $\$ 2$ a day threshold.

The decision to cut the retail price of gasoline under a price modulation arrangement is a welcome development. The cut is expected to curb rising inflation, especially food price inflation which will mainly benefit the poor. However, rather than the price capping regime introduced, by which it is expected of the Petroleum Products Price Regulation Agency (PPPRA) to constantly issues monthly guide on appropriate pricing regime. It is expected that the government will use this opportunity to completely deregulate the petroleum industry in line with existing suggestions and reports. In the event that the global economy becomes healthier and crude oil prices increases, the government might return to the under-recovery of the oil price shortfall by the Nigerian National Petroleum Corporation (NNPC). A policy that annually costs the government huge revenue and recurring losses to the NNPC.

Basically, the Nigerian government essentially must lead economic diversification drive. It is one practicable way to saddle through the current economic uncertainties and instabilities. What the consequences of COVID-19 pandemic should further offer the Nigerian economic managers and policymakers, is that the onetracked, monolithic reliance on oil is failing. Diversification priorities to alternative sectors such as agriculture, solid minerals, manufacturing and services sectors, should be further intensified.

\section{AIM}

The aim of this study was to determine the psychosocial implications of the COVID-19 pandemic.

\section{Methodology}

The study was done through review of the available health service records in the hospital from December 2019 to mid-April, 2020. 
Socio-Economic Implications of the Coronavirus Pandemic: Early Review and Projections, Nigeria in Focus

Approval was obtained from the hospital ethical committee to access the records. These were also followed active search of available online data from the Nigerian Centre for Disease Control (NCDC) and other countries Centre for
Disease Control, the World Health Organization as well as emerging literatures. As it was not possible to do a true systematic review, this was only a narrative review. Data were presented in tables.

\section{RESULTS}

Table1. Age and Sex Distribution of confirmed COVID-19 cases in Nigeria (1 $7^{\text {th }}$ of April, 2020)

\begin{tabular}{|c|c|c|}
\hline Age Group & Frequency & Percentage \\
\hline $0-9$ yrs & 15 & 3.04 \\
\hline 1019 years & 44 & 8.9 \\
\hline 20-29 years & 71 & 14.4 \\
\hline 30-39 years & 96 & 19.5 \\
\hline $40-49$ years & 103 & 20.9 \\
\hline $50-59$ years & 78 & 15.8 \\
\hline 60-5 years & 53 & 10.8 \\
\hline 70-79 years & 21 & 4.2 \\
\hline Above 89 years & 12 & 2.4 \\
\hline Sex & & $70.3 \%$ \\
\hline Male & 347 & $29.6 \%$ \\
\hline Females & 146 & \\
\hline
\end{tabular}

Table2. Socio-demographic characteristics of recorded deaths from COVID 19 in Nigeria(17 ${ }^{\text {th }}$ of April, 2020)

\begin{tabular}{|c|c|c|}
\hline Age & Frequency $(\mathrm{n}=17)$ & $\%$ \\
\hline$<25$ & 2 & $11.98 \%$ \\
\hline$>25$ & 15 & $88 \%$ \\
\hline Sex & & $47.1 \%$ \\
\hline Males & 9 & $52.9 \%$ \\
\hline Females & & $100 \%$ \\
\hline Education & 17 & $0 \%$ \\
\hline Secondary education & 0 & $35.3 \%$ \\
\hline No formal education & 6 & $64.7 \%$ \\
\hline History of Recent Travel outside Nigeria & 11 & \\
\hline No history of travel & & \\
\hline History of travel & & \\
\hline
\end{tabular}

Table3. General fact sheet (April 17, 2020)

\begin{tabular}{|c|c|c|c|c|c|c|c|c|}
\hline States & $\begin{array}{c}\text { Total } \\
\text { Confirmed } \\
\text { Cases }\end{array}$ & $\begin{array}{c}\text { New } \\
\text { Confirmed } \\
\text { Cases }\end{array}$ & $\begin{array}{c}\text { Total } \\
\text { Confirmed } \\
\text { Cases }\end{array}$ & $\begin{array}{c}\text { New } \\
\text { Confirmed } \\
\text { Cases }\end{array}$ & $\begin{array}{c}\text { Total } \\
\text { Deaths }\end{array}$ & $\begin{array}{c}\text { New } \\
\text { Deaths }\end{array}$ & $\begin{array}{c}\text { Total } \\
\text { Active } \\
\text { Cases }\end{array}$ & $\begin{array}{c}\text { Days } \\
\text { Since Last } \\
\text { Reported } \\
\text { Cases }\end{array}$ \\
\hline Lagos & 283 & 32 & 90 & 0 & 11 & 4 & 182 & 0 \\
\hline FCT & 69 & 2 & 23 & 0 & 2 & 0 & 44 & 0 \\
\hline Kano & 27 & 6 & 0 & 0 & 1 & 0 & 26 & 0 \\
\hline Osun & 20 & 0 & 17 & 0 & 0 & 0 & 3 & 14 \\
\hline Edo & 15 & 0 & 6 & 1 & 1 & 0 & 8 & 3 \\
\hline Oyo & 15 & 2 & 5 & 0 & 0 & 0 & 10 & 0 \\
\hline Ogun & 10 & 1 & 5 & 0 & 0 & 0 & 5 & 0 \\
\hline Katsina & 9 & 2 & 0 & 0 & 1 & 0 & 8 & 0 \\
\hline Kwara & 9 & 5 & 0 & 0 & 0 & 0 & 8 & 7 \\
\hline Kaduna & 6 & 0 & 4 & 4 & 0 & 0 & 2 & 9 \\
\hline Bauchi & 6 & 0 & 3 & 0 & 0 & 0 & 8 & 3 \\
\hline AkwaIbom & 6 & 0 & 3 & 0 & 0 & 0 & 0 & 0 \\
\hline Delta & 4 & 0 & 0 & 0 & 1 & 0 & 3 & 2 \\
\hline Ondo & 3 & 0 & 0 & 0 & 0 & 0 & 3 & 4 \\
\hline Ekiti & 3 & 1 & 2 & 1 & 0 & 0 & 1 & 11 \\
\hline Rivers & 2 & 0 & 2 & 1 & 0 & 0 & 0 & 2 \\
\hline
\end{tabular}


Socio-Economic Implications of the Coronavirus Pandemic: Early Review and Projections, Nigeria in Focus

\begin{tabular}{|c|c|c|c|c|c|c|c|c|}
\hline Niger & 2 & 0 & 0 & & 0 & 0 & 2 & 21 \\
\hline Enugu & 2 & 0 & 2 & 0 & 0 & 0 & 0 & 0 \\
\hline Benue & 1 & 0 & 0 & 0 & 0 & 0 & 1 & 20 \\
\hline Anambra & 1 & 0 & 0 & 0 & 0 & 0 & 1 & 7 \\
\hline Total & 493 & 51 & 159 & 7 & 17 & 4 & 317 & \\
\hline
\end{tabular}

Table4. Basic Hospital statistics (University o Port Harcourt Teaching Hosptap, Port Harcourt (17 $7^{\text {th }}$ of April, 2020)

\begin{tabular}{|c|c|}
\hline Attendance in Outpatient Clinic & No. of Patients \\
\hline January & 14,736 \\
\hline February & 13,257 \\
\hline March & 11,103 \\
\hline Monthly Income & \% Decrease \\
\hline December & $2 \%$ \\
\hline January & $9 \%$ \\
\hline February & $15 \%$ \\
\hline March & $14 \%$ \\
\hline annual leave application & No of Staff \\
\hline December & 2.5 \\
\hline January & 31 \\
\hline February & 60 \\
\hline March & 71 \\
\hline
\end{tabular}

\section{DISCUSSION}

The Covid-19 pandemic has alarming social and economic implications for individual as well as the population. ${ }^{1-3}$ Globally, there is contracted economy. ${ }^{25-32}$ The World Bank and IMF have stated that African nations economy will be contracted by $1.6 \%-3 \%$ due to the COVID-19 pandemic. $^{37-39}$ There is equally collapse of different categories of businesses and occupations. ${ }^{27-29,33-36}$ The small scale businesses and labours include those on daily paid jobs Such as builders, petty traders, automobile mechanics, radio mechanics, tailors, food vendors, cinema house operators and workers in entertainment industries. ${ }^{27-29,32-35}$ These represent the non-manufacturing small scale industries. About $90 \%$ of them have inability to operate now in the wake of COVID-19 pandemic. $^{27-29,18}$

Similarly, the medium scale industries such are private clinics with staff not less than 25 , ICT outfit, Proprietors of schools, training centers and NGOs have suffered the same fate due to lack of activities and poor patronage occasioned by the lockdown. ${ }^{40-44}$ There is continuous loss of about $50 \%$ of their daily earnings(AIT documentary series in March).

The coronavirus disease 2019 (COVID-19) pandemic - and the social distancing measures that many countries have implemented-has caused disruptions to daily routines. ${ }^{24-26}$ As of April 8, 2020, academic activities have been suspended nationwide in 188 countries, according to UNESCO. ${ }^{25}$ Over $90 \%$ of enrolled learners ( 1.5 billion young people) worldwide are now out of education. The UNESCO Director-General Audrey Azoulay warned that "the global scale and speed of the current educational disruption is unparalleled. ${ }^{25}$

A loss of an academic year is likely because most schools have hardly covered up to $50 \%$ of the academic work for the academic session before the lockdown. ${ }^{25,26}$ This relates to the fact that the closure occurred barely half way of the second term for the primary and secondary schools, and from the beginning of the first semester for the post-secondary schools at different levels. ${ }^{25,26}$ This represents one of the important social arenas for the children and adolescents. Schools avail them the opportunity to be actively engaged and therefore provide a health mind and ensure good mental health for children and adolescents. It also helps to remove boredoms for those who may not find anything doing at home for the psychologically vulnerable minds as well as those with emotional problems, schools remain a potent social ground and often offers a therapeutic network.

For children and adolescents with mental health needs, such closures mean a lack of access to the resources they usually have through schools. In a survey by the mental health charity Young Minds, which included 2111 participants up to age 25 years with a mental illness history in the UK, $83 \%$ said the pandemic had made their conditions worse. $26 \%$ said they were unable to 
access mental health support; peer support groups and face-to-face services have been cancelled, and support by phone or online can be challenging for some young people. School routines are important coping mechanisms for young people with mental health issues. When schools are closed, they lose an anchor in life and their symptoms could relapse. "Going to school had been a struggle for some children with Depression prior to the pandemic, but at least they had school routines to stick with". ${ }^{25,26}$

Furthermore, most annual sporting and competition events were postponed indefinitely. ${ }^{45-}$ ${ }^{47}$ In Nigeria, the Annul Sport Festival was Equally postponed indefinately after the host States have invested copiously hoping to recoup the expense during the national sports event with intending participating States who had spent a lot of resources preparing their participants. Delta and Kano States had this misfortune.

COVID 19 also appears to be heightening in spate of insecurity as youths claiming to be Cult members recently heightened aggression to dispossess their victims of money and food items to feed themselves. The press has been inundated with reports of violent crimes, act of brigandage and lawlessness which were all directed at dispossessing mostly vulnerable individuals including females, children and elderly men of their possessions in their various homes and lonely locations at Lagos, Ogun, Edo and Kano. However, this has not been reported in Port Harcourt. Similarly, Social distancing measures and the subsequent stay-at-home policy can result in social isolation in an Abusive home, with abuse likely exacerbated during this time of economic uncertainty, hardship and stress. ${ }^{48-50}$ Jianli County in Hubei province, China, has seen reports of domestic violence to the law enforcement agents more than escality during the lockdown in February, from 47 last year to 162 this year. Increased rates of Child Abuse, Neglect, and exploitation have also been reported during previous Public Health Emergencies, such as the Ebola outbreak in west Africa from 2014 to 2016.

The International Monetary Funds (IMF) said that out of the USD114B for Africa, Nigeria needs USD11B.In Nigeria, a number of palliative measures have been put in place by government at both the federal and state levels. The Central bank of Nigeria $(\mathrm{CBN})$ announced a CBN COVID-19 Palliative measure with the release of three Billion Naira for the poor and the vulnerable. States in Nigeria have equally rolled out a number of palliative measures. Most States have set up State COVID-19 Taskforce for distribution of palliative materials and enforcement of preventive measures involving Local Government Officials, Chiefs and Elders of Communities, Youth and Women Leaders, as seen in Rivers State particularly and few other States. These platform is worthy of emulation because it is all encompassing and gives a significant coverage of the rural communities and the most vulnerable Nigerians.

This task force headed by a seasoned administrator is highly commendable due to its non-partisan and transparent stand. Furthermore, the Rivers State Government should be commended for voting two billion naira to cushion the effects of COVID-19 pandemic. Even if this is not adequate, it is reasonable for a State, and therefore highly applauded.

An issue of concern is the apparent unpreparedness that was reflected in the manner the Federal Government appeared to have deployed poorly coordinated palliative programmes. ${ }^{51}$ However, the public outcry, inputs of public commentators and the Presidential intervention stemmed the slide as most anomalies have been fairly amended such as increase the number of households in Nigeria from One million and forty six to two million and forty six households who now benefit from the Social Investment Programmes. This still remains abysmal since by WHO records about 40million Nigerians are poor.

There have also been other ideas such as making use of the BVN of individuals who have Bank Accounts to verify those who may benefit from these outlined palliative measures. However, these have further exposed the lapses in our harnessing of vital socio-economic statistics and the poor census activities in the past, occasioned by persistent political ill-will by the so-called ruling class. Out of the 3 to 4 population census exercises conducted between 1958 till date, not one has been adjudged satisfactory as the political elites continue to manipulate these figures for their selfish and pecuniary interest.

This is therefore, a clarion call for a strong, reliable, socio-investment projects that will equally guarantee social security and overall peace and well-being of the citizenry of the Federal Republic of Nigeria. It is worthy of note that the Sovereign Wealth Reserved of the last administration of President Good luck Jonathan, though politically castigated, showed high economic benefits that could be attested to by 
the present administration leaning on it to move some funds, as it saw it a ready pillar to rest on and has equally harvested some benefit from it at this globally challenging time.

With the projection of World Bank and the IMF of a global Recession that may be sustained towards the end of 2021, and with the Budgetary Review of Annual Budget 2020 that the Federal Government in Nigeria that led to the cut of both Educational and Health Budget by $25 \%$ each, it is important to act fast and prudently too. Hence, the need for a review of the economic blue print with technocrats, financial experts, policy strategists, Agro Professional and farmers to preserve our National and food Security and to prevent poverty, anarchy, famine, hunger and restiveness. . This will further create prosperity for other farmers and buffer that the economic and financial experts in the nation should rise up and begin to have consultations even with the agriculturists and the ministry of agriculture so as to sustain adequate food for the sustenance of these people, prosperity of farmers and to buffer the oil losses accruing from global oil losses. ${ }^{40-}$ ${ }^{45}$ Hoarding limited supplies is not a sustainable model for an economy. It creates a cycle of fear and anticipatory deprivation. Likewise, people pulling out investment from the economy are indeed creating the very conditions for economic collapse. Our way of life is based on trust and connection; these invisible threads that bind us also create the foundation for a stronger economy.

It will be most disastrous if such strategies are not put in place because in the next two years, more would have died from famine in Nigeria than the deaths recorded from COVID-19. By this strategy, we would have averted deaths that may occur from energy Protein Energy Malnutrition leading to high susceptibility to infections mostly among children particularly the Under-5.

Though it is challenging to be analytical about the stress in our lives during a time of peak anxiety and clearly unbearable difficulties or unease, sustaining our way of life would always require exactly this. We therefore need to move our thoughts from the fight-or-flight system into the highest plane of who we and consider our deeper values, and how we can make hard decisions right now to prevent social and economic collapse.

Public health emergencies may affect the Health, Safety, and well-being of both individuals (causing, for example, insecurity, confusion, emotional isolation, and stigma) and communities owing to economic loss, work and school closures, inadequate resources for medical response, and deficient distribution of resources and necessities of life. These effects may translate into a range of emotional reactions (such as distress or psychiatric conditions), unhealthy behaviors such as excessive substance use and violence and noncompliance or disobedience to Public Health directives such as home confinement and social distancing in people who contract the disease and in the general population. Extensive research in disaster Mental Health has established that emotional distress is ubiquitous in affected populations - a finding certain to be replicated in populations affected by the Covid-19 pandemic.

\section{FUTURE Directions RECOMMENDATIONS}

AND

1. Nations should dedicate substantial portion of funds to cushion the hardship suffered by their citizens particularly the vulnerable ones. In addressing these daunting economic challenges, the current considerations to revise the budget downward is inevitable. However, certain considerations that are expected in the review must not be left out. The assumptions and benchmarks must be based on realizable thresholds and estimates to ensure optimum budget performance, especially on the non-oil revenue components.

2. Furthermore, cutting expenditures must be done such that the already excluded group and vulnerable are not left to bear the brunt of the economic contraction. The economic and growth recovery program which has the aim of increasing social inclusion by creating jobs and providing support for the poorest and most vulnerable members of society through investments in social programs and providing social amenities will no doubt suffers some setbacks. Besides, the downward review of the budget and contractions in public spending could be devastating on poverty and unemployment.

3. Countries should review their restrictions in line with the evolving epidemiology of the pandemic.

4. As the pandemic continues, it is important to support children and adolescents facing bereavement and issues related to parental unemployment or loss of household income. 
5. There is also a need to monitor young people's mental health status over the long term, and to study how prolonged school closures, strict social distancing measures, and the pandemic itself affect the wellbeing of children and adolescents.

6. Self-care for providers, including Mental Health care providers, involves being informed about the illness and risks, monitoring one's own stress reactions, and seeking appropriate assistance with personal and professional responsibilities and concerns.

7. Health care systems will need to address the stress on individual providers and on general operations by monitoring reactions and performance, altering assignments and schedules, modifying expectations, and creating mechanisms to offer psychosocial support as needed.

8. Reform and engage optimal prudence in the implementation of our National Health Insurance

\section{REFERENCES}

[1] The economic impact of coronavirus: analysis from Imperial experts | Imperial News | Imperial College London [Internet]. Imperial News. [cited 2020 Apr 6]. Available from: https://www.imperial.ac.uk/news/196514/theeconomic-impact-coronavirus-analysis-from/

[2] Coronavirus: Travel restrictions, border shutdowns by country | Coronavirus pandemic News | Al Jazeera [Internet]. [cited 2020 Mar 20]. Available from: https://www.aljazeera. com/news/2020/03/coronavirus-travel-restricti ons-border-shutdowns-country-200318091505 922.html

[3] Prices of agricultural commodities drop 20\% post COVID-19 outbreak - Rediff Realtime News [Internet]. [cited 2020 Mar 20]. Available from: https://realtime.rediff.com/ news/ india/ Prices-of-agricultural-commodities-drop-20post-COVID19-outbreak/ 955078599584b749 ? src=interim_alsoreadimage

[4] Bogoch, A. Watts, A. Thomas-Bachli, C. Huber, M.U.G. Kraemer, K. Khan, Pneumonia of unknown etiologyu in wuhan, China: potential for international spread jvia commercial air travel, J. Trav. Med. (2020),

[5] Lu, C.W. Stratton, Y.W. Tang, Outbreak of pneumonia of unknown etiolokgy in wuhan China the mystery and the miracle, J. Med. Virol. 92 (4) (2020) 401-402.

[6] Cleri DJ, Ricketti AJ, Vernaleo JR. Severe acute respiratory syndrome (SARS) Infect. Dis. Clin. North Am. 2010;24:175-202. • Reviews the sources of severe acute respiratory syndrome coronavirus (SARS-CoV) in nature.

[7] Adhikari S.P., Meng S., Wu Y.-J., Mao Y.-P., Ye R.-X., Wang Q.-Z., Sun C., Sylvia S., Rozelle S., Raat H., Zhou H. Epidemiology, causes, clinical manifestation and diagnosis, prevention and control of coronavirus disease (COVID-19) during the early outbreak period: a scoping review. Infect. Dis. Poverty. 2020;17(9):29.

[8] A. Du Toit, outbreak of a novel coronavirus, Nat. Rev. Microbiol. 18 (123) 2020), https://doi:org/10.1038/41579-020-0332-0.

[9] L.L Ren, Y.M. Wang, Z,Q.Wu, Z.C Xiang, L. Guo, T. $\mathrm{Xu}$, et al., identification of a novel coronavirus causing serve pneumonia in $\mathrm{j}$ human a descriptive study, Chinese Med J (2020).

[10] H. Nishiura, S.M. Jung. N.M. Linton, R. Kinoshita, Y. Yang, K. Hayashi, et al, the extent of transmission of novel coronavirus in Wuhan, China, 2020, J. Clin. Med. 9 (2020).

[11] M. Bassetti, A. Vena, D. Roberto Giacobbe, The Novel Chinese coronavirus (2019-nCoV) Infection: challenges for fighting the storm, Eur. J. Clin. Invest. (2020).

[12] M.I. Holshue, C. DeBolt, S. Lindquist, K.H. Loy, J. Wiesman, H. Bruce, et al., first case 2019 novel coronavirus in the United States, N.Engl. J.Med. (2020).

[13] Sohrabi C., Alsafi Z., O’Neill N., Khan M., Kerwan A., Al-Jabir A. World Health Organization declares global emergency: A review of the 2019 novel coronavirus (COVID19) Int J Surg. 2020 Apr;76:71-76.

[14] Buck T, Arnold M, Chazan G, Cookson C. Coronavirus declared a pandemic as fears of economic crisis mount [Internet]. 2020 [cited 2020 Mar 19]. Available from: https://www.ft.com/content/d72f1e54-639611ea-b3f3-fe4680ea68b5

[15] Rolling updates on Coronavirus disease (COVID-19), $20^{\mathrm{TH}}$ April, 2020; WHO.

[16] ITU-WHO Joint Statement unleashing information technology to defeat COVID-19.

[17] Rapid risk assessment: Coronavirus disease 2019(COVID-19) in the EU/EEA and the UK$9^{\text {th }}$ Update, $23^{\text {rd }}$ April, 2020.

[18] Nigerian Center for Disease Control (NCDC). National Strategy to scale up Access to Coronavirus disease testing in Nigeria, $20^{\text {th }}$ April, 2020. CDC

[19] Loeb AB Avi. Flattening the COVID-19 Curves [Internet]. Scientific American Blog Network. [cited 2020 Mar 20]. Available from: https://blogs.scientificamerican.com/observatio ns/flattening-the-covid-19-curves/

[20] OPEC's pact with Russia falls apart, sending oil into tailspin. Reuters [Internet]. 2020 Mar 6 
[cited 2020 Mar 23]; Available from: https://www.reuters.com/article/us-opec-meeti ng-idUSKBN20T0Y2

[21] Oil Prices, Stocks Plunge After Saudi Arabia Stuns World With Massive Discounts [Internet]. NPR.org. [cited 2020 Mar 23]. Available from: https://www.npr. org/2020/ 03/08/813439501/saudi-arabia-stuns-worldwith-massive-discount-in-oil-sold-to-asiaeurope-and-u-

[22] Breakeven Oil Prices Underscore Shale's Impact on the Market [Internet]. [cited 2020 Mar23]. Available from: https://www. da llasfed.org:443/research/economics/2019/0521

[23] Coronavirus: Travel restrictions, border shutdowns by country | Coronavirus pandemic News | Al Jazeera [Internet]. [cited 2020 Mar 20]. Available from: https://www.aljazeera. com/news/2020/03/coronavirus-travel-restrictio ns-border-shutdowns-country-2003180915059 2 2.html

[24] Guidance on social distancing for everyone in the UK [Internet]. GOV.UK. [cited 2020 Mar 22]. Available from: https://www. gov.uk/ government/publications/covid-19-guidance-on -social-distancing-and-for-vulnerable-people /guidance-on-social-distancing-for-everyonein-the-uk-and-protecting-older-people-andvulnerable-adults

[25] https://plus.google.com/+UNESCO. COVID-19 Educational Disruption and Response [Internet]. UNESCO. 2020 [cited 2020 Mar 20]. Available from: https://en.unesco. org/ themes/education-emergencies /coronavirus school-closures

[26] Social and economic impact of school closure resulting from pandemic influenza $\mathrm{A} / \mathrm{H} 1 \mathrm{~N} 1$ Journal of Infection [Internet]. [cited 2020 Mar 20]. Available from: https://www.journal of infection.com/article/S0163-4453(11)00008-9/ fulltext

[27] Keogh-Brown M.R., Wren-Lewis S., Edmunds W.J., Beutels P., Smith R.D. The possible macroeconomic impact on the UK of an influenza pandemic. Health Econ. 2010; 19 (11):1345-1360.

[28] Impey C. Coronavirus: Social distancing is delaying vital scientific research [Internet]. The Conversation. [cited 2020 Mar 21]. Available from: http://theconversation.com/coronavirussocial-distancing-is-delaying-vital-scientificresearch-133689

[29] Yap C.-W. China's Factories Struggle to Resume Operations After Virus Shutdown. Wall Street Journal. 2020 Feb 8 https://www.wsj.com/articles/chinas-factoriesstruggle-to-resume-operations-after-virusshutdown-11581157800 [Internet] [cited 2020 Mar 20]; Available from: [Google Scholar]
[30] 10 Year Treasury Rate [Internet]. [cited 2020 Apr 7]. Available from: https:// ycharts. com/ indicators/10_year_treasury_rate

[31] Smith YL Elliot. 10-year yield dives below $0.7 \%$ after Fed announces unlimited asset purchases [Internet]. CNBC. 2020 [cited 2020 Mar 23]. Available from: https://www. cnbc.com/2020/03/23/treasury-yields-fall-ascoronavirus-cases-rise-relief-bill-stalls.html

[32] The economic impact of COVID-19 | Deloitte Insights [Internet]. [cited 2020 Mar 19]. Available from: https://www2.deloitte. Com /global/en/insights/economy/covid-19/econom ic-impact-covid-19.html

[33] Mitigating the COVID Economic Crisis: Act Fast and Do Whatever It Takes | VOX, CEPR Policy Portal [Internet]. [cited 2020 Mar 20]. Available from: https://voxeu. org/content /mitigating-covid-economic-crisis-act-fast-anddo-whatever-it-takes

[34] Europe's economic rescue packages worth combined $€ 1.7$ tn $\mid$ World news | The Guardian [Internet]. [cited 2020 Mar 20]. Available from: https://www.theguardian.com/world/2020/mar/ 19/europes-economic-rescue-packages-worthcombined-17tn

[35] Germany unleashes biggest post-war aid package against virus [Internet]. CNA. [cited 2020 Mar 20]. Available from: https://www. channelnewsasia.com/news/business/germanyunleashes-biggest-post-war-aid-packagecoronavirus- 12536540

[36] UK to pay wages for workers facing job losses. BBC News [Internet]. 2020 Mar 20 [cited 2020 Mar 22]; Available from: https://www.bbc. com/news/business-51982005

[37] Banking and capital markets: Implications of COVID-19 | Deloitte Insights [Internet]. [cited 2020 Mar 20]. Available from: https://www2. deloitte.com/global/en/insights/economy/covid19/banking-and-capital-markets-impact-covid19.html

[38] Smialek J. Fed Official Says Central Bankers Are Aligned in Coronavirus Response. The New York Times [Internet]. 2020 Mar 5 [cited 2020 Mar 20]; Available from: https://www. nytimes.com/2020/03/05/business/economy/fed -rate-cut-coronavirus.html

[39] Bank of Japan pumps \$43b in liquidity, largest amount since 2008, Economy News \& Top Stories - The Straits Times [Internet]. [cited 2020 Apr 6]. Available from: https://www. straitstimes.com/business/economy/bank-ofjapan-pumps-43b-in-liquidity-largest-amountsince-2008

[40] Tanne JH, Hayasaki E, Zastrow M, Pulla P, Smith P, Rada AG. Covid-19: how doctors and healthcare systems are tackling coronavirus worldwide. BMJ [Internet]. 2020 Mar 18 [cited 2020 Mar 20];368. Available from: https:// www.bmj.com/content/368/bmj.m1090 
[41] COVID-19 USA: Coronavirus outbreak measures and effect on the US [Internet]. [cited 2020 Mar 20]. Available from: https:// www. pharmaceutical-technology.com/features/ coronavirus-affected-countries-usa-covid-19measures-impact-pharma-hotel-tourism-medical/

[42] Commentary: COVID-19, the biggest crisis ever for Singapore's aviation industry and Singapore Airlines - CNA [Internet]. [cited 2020 Mar 20]. Available from: https://www. channelnewsasia.com/news/commentary/covid19-coronavirus-airline-sia-flight-air-travelindustry-cut-12542996

[43] U.S. airlines seek $\$ 50$ billion coronavirus bailout to avoid collapse. Reuters [Internet]. 2020 Mar 16 [cited 2020 Mar 20]; Available from: https://in.reuters.com/article/uk-healthcoronavirus-usa-aviation-idINKBN21337Q

[44] UK airlines call for multibillion bailout to survive Covid-19 crisis | World news | The Guardian [Internet]. [cited 2020 Mar 20]. Available from: https://www. theguardian. com/world/2020/mar/15/uk-airlines-call-formultibillion-bailout-to-survive-covid-19-crisis

[45] Pickford J. Coronavirus fears hit UK property market as viewings dry up [Internet]. 2020 [cited 2020 Mar 20]. Available from: https:// www.ft.com/content/e30ccb84-6799-11ea800d-da70cff6e $4 d 3$

[46] UEFA.com. UEFA EURO 2020 [Internet]. UEFA.com. [cited 2020 Mar 20]. Available from: https://www.uefa.com/uefaeuro-2020/
[47] Tokyo Olympics postponed to 2021 due to coronavirus pandemic | Sport | The Guardian [Internet]. [cited 2020 Apr 7]. Available from: https://www.theguardian.com/sport/2020/mar/2 4/tokyo-olympics-to-be-postponed-to-2021due-to-coronavirus-pandemic

[48] Kent E. Coronavirus outbreak forces cancellation of multiple sports events [Internet]. Eurogamer. 2020 [cited 2020 Apr 8]. Available from: https://www.eurogamer.net/articles/202001-30-coronavirus-outbreak-forcescancellation-of-multiple-esports-events

[49] Coronavirus: Domestic abuse calls up 25\% since lockdown, charity says - BBC News [Internet]. [cited 2020 Apr 7]. Available from: https://www.bbc.co.uk/news/uk-52157620

[50] 25\% increase in calls to National Domestic Abuse Helpline since lockdown measures began - Refuge Charity - Domestic Violence Help [Internet]. [cited 2020 Apr 7]. Available from: https://www.refuge.org.uk/25-increasein-calls-to-national-domestic-abuse-helplinesince-lockdown-measures-began/

[51] Domestic abuse: how to get help - GOV.UK [Internet]. [cited 2020 Apr 7]. Available from: https://www.gov.uk/guidance/domestic-abusehow-to-get-help

[52] Resilient leadership responding to COVID-19 | Deloitte Insights [Internet]. [cited $2020 \mathrm{Mar}$ 20]. Available from: https://www2. deloitte. com/global/en/insights/economy/covid19/heart-of-resilient-leadership-responding-tocovid-19.html

Citation: Stanley C N et al., "Socio-Economic Implications of the Coronavirus Pandemic: Early Review and Projections, Nigeria in Focus", International Journal of Research Studies in Medical and Health Sciences. 2020; 5(4): 40-49.

Copyright: (C) 2020 Stanley $C N$ et al., This is an open-access article distributed under the terms of the Creative Commons Attribution License, which permits unrestricted use, distribution, and reproduction in any medium, provided the original author and source are credited. 